\title{
ITC, Is this a degree for blind people?
}

\section{TIC, ¿Carrera para débiles visuales?}

\author{
TOVAR-GONZÁLEZ, Claudia†*, GARCÍA-CEDILLO, David Rey and TIJERINA-MARTÍNEZ, \\ Felipe
}

\section{Universidad Tecnológica Santa Catarina}

ID $1^{\text {st }}$ Author: Claudia, Tovar-González / ORC ID: 0000-0001-5785-0792, Researcher ID Thomson: E-6006-2019, CVU CONACYT ID: 992306

ID $1^{\text {st }}$ Coauthor: David Rey, García-Cedillo / ORC ID: 0000-0001-5914-7718, Researcher ID Thomson: E-6178-2019, CVU CONACYT ID: 728974

ID $2^{\text {nd }}$ Coauthor: Felipe, Tijerina-Martínez / ORC ID: 0000-0003-0591-228X, Researcher ID Thomson: E-6006-2019, CVU CONACYT ID: 249445

DOI: $10.35429 / J H E W .2019 .5 .3 .8 .16$

Received September 05, 2019; Accepted December 30, 2019

\begin{abstract}
Goals: Analyze, the inclusion of disabled people in education or work, because some schools offer the opportunity of studying a degree, giving learning tools in the way they can develop the competences for working. The Technological University of Santa Catarina created a program called Disabled Attention Program (DAP) in 2004. At the beginning just deaf people were assisted, but little by little people with other disabilities were integrated in the program, like blind, handicapped and intellectual disability people. The educative programs offered by the university are: Industrial processes, Business development, Mechatronics, Information technology and communication and others. Methodology: We did a qualitative analysis focused on the career of Information and communication technologies, on blind students, although the number of students has been limited to a few, just 2 of them have finished their career and the others have quit for many reasons. In this case the tool is a survey made of open and closed questions. The principal contribution of this research is to guide the students in a better way, by demonstrating them the real context of the career, so they can make a good decision about what they want to study.
\end{abstract}

Inclusion, Handicap, Blindness

\begin{abstract}
Resumen
Objetivos: Analizar el tema de la inclusión de personas con discapacidad en el ámbito educativo y laboral, ya que en algunas escuelas se da la oportunidad de estudiar; brindando herramientas necesarias para el desarrollo de las competencias que requieren, para integrarse al mundo profesional. En la Universidad Tecnológica Santa Catarina, se implementó un proyecto llamado Programa de Atención a la Discapacidad (PAD) desde 2004. Al principio se atendían a estudiantes con discapacidad auditiva, pero se han ido integrando otros tipos de discapacidad como visual, motriz e intelectual. Las carreras que se ofertan son: Procesos industriales, Desarrollo de negocios, Mecatrónica, Tecnologías de la Información, entre otras. Metodologia: Se hizo un análisis cualitativo en la carrera Tecnologías de la Información, a alumnos con discapacidad visual, que si bien no se ha contado con muchos, la realidad es que solamente 2 han culminado sus estudios, y el resto ha desertado por diversos motivos. En este caso la herramienta es un cuestionario constituido por preguntas abiertas y de opción múltiple. La contribución principal de esta investigación es guiar al alumno, mostrando una realidad de la carrera, para que pueda tomar la decisión correcta en cuanto a que, estudiar.
\end{abstract}

Inclusión, Discapacidad, Ceguera

Citation: TOVAR-GONZÁLEZ, Claudia, GARCÍA-CEDILLO, David Rey and TIJERINA-MARTÍNEZ, Felipe. ITC, Is this a degree for blind people? Journal Health, Education and Welfare. 2019. 3-5: 8-16

\footnotetext{
* Correspondence to Author (email: tg2000@yahoo.com)

$\dagger$ Researcher contributing as first author
} 


\section{Introduction}

Inclusive education responds to a philosophical, social, economic, cultural, political and pedagogical approach that seeks the acceptance and assessment of differences in school for each of its students. In the inclusive school, students benefit from a teaching adapted to their needs. Educational inclusion is a process that has already begun in many countries, affecting everyone, the whole school, students, parents, teachers, in general the whole society.

(Zappalá, Köppel, \& Suchodolski, 2011)

From birth, much of the learning occurs through vision. $80 \%$ of the information that reaches the brain is through the visual pathway. Therefore, the vision has a very important role in the development of people.

According to WHO defines visual impairment in two terms:

The term "blindness" ranges from 0.05 visual acuity (5\%) to non-perception of light or a reduction of the visual field less than $10^{\circ}$.

The term "low vision" includes a maximum acuity of less than $0.3(30 \%)$ and a minimum of more than $0.05(5 \%)$.

On the other hand, it also classifies visual impairment to different degrees, based on visual acuity and visual field.:

Normal vision: visual acuity 0.8 or better $/ 120^{\circ}$ field of view

Low moderate vision: visual acuity $<0.3$ / visual field $<60^{\circ}$

Low severe vision: visual acuity $<0.12$ / visual field $<20^{\circ}$

Low deep vision: visual acuity $<0.05$ / visual field $<10^{\circ}$

Almost total blindness: visual acuity $<0.02$ / visual field $<5^{\circ}$

Total blindness: visual acuity: no light perception / visual field $0^{\circ}$ (Alberti \& Romero, 2010)

\section{Causes of visual impairment}

Visual impairment can appear for many reasons, depending on the part of the process or organ of vision that is affected; although normally, the most frequent are those that affect the eyeball, highlighting as the most important those mentioned below:

\section{Hereditary}

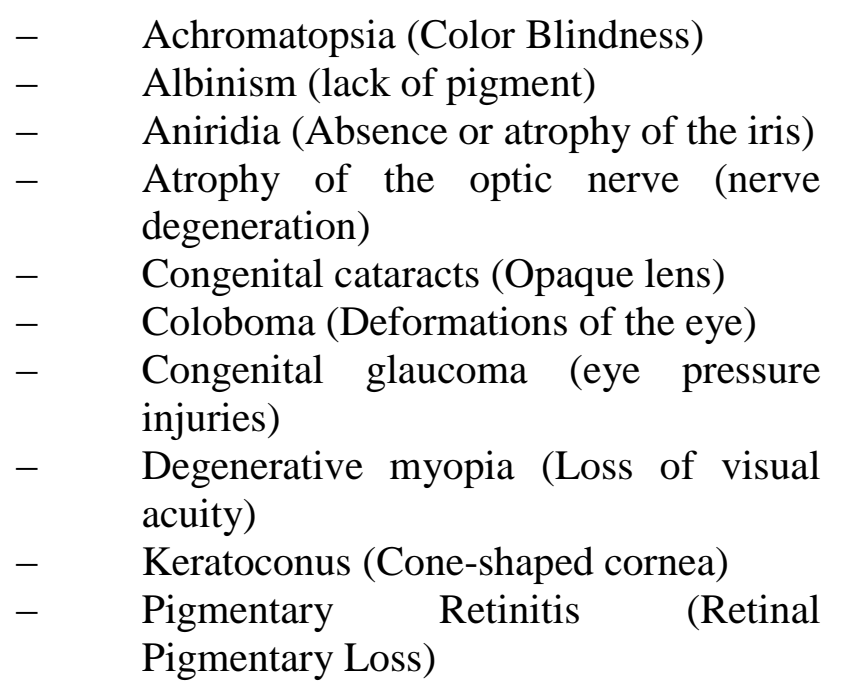

\section{Congenital}

- $\quad$ Anophthalmia (lack of eyeball)

- Atrophy of the optic nerve (nerve degeneration)

- Congenital cataracts (Opaque lens)

- Microftalmia (poor development of the eyeball)

- $\quad$ Rubella (Viral infection throughout the eye)

Toxoplasmosis (Viral infection in the retina / macula)

Acquired / accidental

\begin{tabular}{|c|c|}
\hline & Avitaminosis (Vitamin Insufficiency) \\
\hline & Traumatic \\
\hline & Crystalline) \\
\hline - & Retinal Detachment (Retinal Injury) \\
\hline- & $\begin{array}{l}\text { Diabetes (Difficulty metabolizing } \\
\text { glucose) }\end{array}$ \\
\hline- & $\begin{array}{l}\text { Papillary stasis } \\
\text { strangulation) }\end{array}$ (optic nerve \\
\hline - & $\begin{array}{l}\text { Retrolental fibroplasty (Retinal / vitreous } \\
\text { conditions) }\end{array}$ \\
\hline- & Adult glaucoma (eye pressure injuries) \\
\hline - & $\begin{array}{l}\text { Hydrocephalus (Accumulation of fluid in } \\
\text { the brain) }\end{array}$ \\
\hline - & $\begin{array}{l}\text { Various infections of the circulatory } \\
\text { system }\end{array}$ \\
\hline & Injuries to the occipital lobe \\
\hline
\end{tabular}

Viral / toxic / tumor:

- $\quad$ Histoplasmosis (Stool Fungal Infection)

- Meningitis (Infection of the cerebral meninges)

Optic neuritis (optic nerve infection)

TOVAR-GONZÁLEZ, Claudia, GARCÍA-CEDILLO, David Rey and TIJERINA-MARTÍNEZ, Felipe. ITC, Is this a degree for blind people? Journal Health, Education and Welfare. 2019 


\section{Behavior of visually impaired people}

Intelligence: they have great capacity to remember auditory material, in the development of language they can present verbalism (words without understanding their meaning).

Personality and socialization: blindisms (repetitive self-stimulations caused by lack of affectivity or environmental stimulation), passivity and inability to adequately cope with environmental situations, feelings of inferiority and poor body image.

Motor: alterations in gait, posture, balance and motor coordination, poor manual ability, absence of communication gestures and presence of tics, stereotyped movements and balances.

\section{Intervention resources for visual impairment}

There are some material resources, which are very useful for the performance in different areas of people with visual disabilities.

Some of them are:

In read writing:

Guideline or strip and punch, for manual braille writing.

Perkins machine, for braille typing.

In draw:

Special drawing folder

In mathematics:

Arithmetic box and abacus

Talking calculator

Other materials:

- $\quad$ Maps and models in relief

- $\quad$ Spoken book

- Thermoform, for embossed copies of drawings and shapes, combined with braille writing.

- Optacon, which allows the blind to read the print

- Versabraille, a freely programmable word processor that stores information.

Braille lines, computer peripheral that translates information into Braille.

Stereoscopic oven, for obtaining relief photographs.
Vert-Plus and Vista card, for computers, translation into oral language and enlarging the characters on the screen, respectively. (Rojas, Palomares Ruiz, \& (coords.), 2014)

In 2004, the Santa Catarina Technological University begins a project called, Disability Care Program (PAD), in which 15 students with hearing disabilities begin to study the career of Information and Communication Technologies.

What was proposed was that instead of taking the regular curriculum ( 2 years), a depressurized plan (3 years) is implemented.

In this, the same academic load is carried, only that fewer subjects are taken per semester. At the time, it was exclusive for people with disabilities, but it has also been a great help for those students who work and study at the same time. On the other hand, the evening shift has implemented this same plan.

In 2008, a person with visual impairment was integrated for the first time, he only knew the Braille system, and even his notes took them with this same method. When he arrives at the third semester, he is discharged by his own decision, since, in this, visual programming subjects begin to be included.

It is until 2013 and currently, when little by little more students with this type of disability are being integrated.

On average, 2 students with visual impairment have been treated per year.

The support that students with visual disabilities have is the use of screen reader software, such as Jaws and Nvda.

The University has a Tiflotecnica room, to enhance drawings and these can be manipulated by touch.

Also, books are digitized, so they can be read with the aforementioned software.

On the other hand, students have their own computer equipment and the university installs the screen reader. 
The main objective of this study is to guide students with this type of disability in a better way, presenting a more complete picture of the career and really knowing what they are going to face, so that they can make a good decision, as to what to study.

\section{Methodology to develop}

The qualitative methodology is used to carry out this research, since the number of students who have enrolled in the degree has not been significant.

Over time, 12 enrolled students have been identified. Of these 12 , one of them successfully completed the race until the sixth semester, but in the seventh I am truncated by death. Another student, being a mother, had to withdraw due to personal problems. 2 more boys only attended the first semester, but not wanting to make the minimum effort even though they were provided with the necessary tools, they dropped out to enter another race. Another student runs until the third semester, suffers an accident and does not continue with the race, another course until third, but withdraws because his desire was to study music.

One boy had to withdraw due to change of residence, and one more student had to withdraw due to illness (multiple sclerosis).

Having been an experiential process and having lived closely with the students in question, a questionnaire was developed to confirm what the students experienced in their educational process.

For this, questionnaires were applied and a response was obtained from 2 success stories (man and woman) that completed the degree, the man concluded until the Engineering in Information and Communication Technologies, the woman finished only the Higher University Technician. The other 2 cases exposed failed to conclude their studies.

The questionnaire contains open and closed questions.
The questions are as follows:

1.- How do you consider the basis of your educational preparation prior to the UTSC to continue studying?
A) Bad
B) Regular
C) Good
D) Excellent

2.- Why choose the Information Technology degree?
A) Higher demand
B) They recommended it to you
C) A friend studied her
D) I didn't know what to study

3.- Do you consider that the UTSC provided you with enough support for your studies?
A) Yes
B) No

4.- Did the UTSC teachers support you to clarify doubts about your vision problems?
A) Yes
B) $\mathrm{No}$
C) Sometimes
D) Always

5.- What support tools have you used in your studies?

A:

6.- Do I use the braille system during the race to take notes of the subjects?
A) Yes
B) No

7.- Do I use the JAWS or NVDA screen reader during the race?

A) Yes

B) No

8.- There were some practices of some subjects where the screen reader will not work, in case the answer is YES answer the following questions: which practices, in which subjects and what option did the teacher give them to perform these practices.
A) Yes
What are you practicing?
What subjects?
How did the teacher solve it?
B) No 
9.- Did you finish the career of TSU or Engineering in Information and Communication Technologies?
A) Yes
B) No

9.1.- If your answer was negative, mention the reason why you did not finish your studies

A:

10.- What do you do now?

A:

What is the cause of your blindness?

How was your school development from childhood to adolescence?

How is your current family life?

What have been the most difficult obstacles in your life?

Where did you do high school?

When you chose the ICT career, did you really know what awaited you?

How was your life with your other group partners?

If you did not finish your career, answer the following question:

What was the reason for not finishing the race? In which branch of ICT do you feel you are most capable?

If you finished your career answer the following question:

What were your expectations at the end of the race?

What is your economic status?

\section{Discussion and analysis of results}

Since 2008, the year in which a person with visual impairment is attended for the first time, which does not culminate in his studies, and 5 years later and to date, they have joined the career of Information and Communication Technologies 12 students with visual impairment.

Although there have not been many, when they unsubscribe, they increase the dropout rate. This may not be significant but for the race itself.

Only 2 students, one woman and one man, have finished. The girl finished only the Higher University Technician and the boy the Engineering in Information and Communication Technologies.
Below are the 2 students who dropped out (a man and a woman) and then the other 2 students who did finish.

It starts with students who did not finish the race. The first subject is a woman, the cause of her blindness is from birth, since the optic nerve did not develop.

Her school development was very normal, and she also had some support teachers and took additional classes to improve her academic performance.

The high school was carried out at the CECYTE Nuevo León extension Santa Catarina, (located within the facilities of the university), considers that its preparation before entering the university was excellent.

When I finish high school, I didn't know what to study, but I have always been interested in computers and learning programming, so I chose the ICT career because it has a greater demand in companies.

She says that the university gave her enough help and that the teachers always supported her. The support tools you have used are the computer, e-books, as well as having screen readers like Jaws and NVDA.

When I study at the university, I do not use the Braille system although I do know it.

In the practices that had problems it was in the matter of database, but the teacher always had the disposition to help her, and I even install the screen reader to understand how the student could interact with the program and solve the doubts that were presented.

This student did not finish the race for personal reasons that she does not mention, in addition to having had some economic problems and lack of transportation. Here it is worth mentioning that the university has transportation, but the student had to move to the point where it passed.

She currently has a scholarship and is studying for a degree in education and information and communication technologies at the University of Northern Tamaulipas. 
In this particular university they have already had the experience of having students with visual disabilities, so they already know how they should be treated. Materials are shared electronically.

She does not live much with her family since she is living in Nuevo Laredo, Tamaulipas. And some of the obstacles he has faced are ignorance of people who put limits on them and fear of doing something unknown.

The second subject of study is a man, the cause of her blindness is a retinopathy for being born prematurely. Her school development was normal, although she had some problems with her dad since she didn't want to support him.

It is middle class, their family life is good, and considers that all people have obstacles, but in their case is the inclusion in a school. Since many teachers and classmates do not accept or do not want to work with people with disabilities. Although she has also met good people and teachers.

The support tools I used in elementary school were the braille machine and a computer in middle and high school.

The bases of her educational preparation prior to the UTSC considers them good and this was carried out in the high school 9 of the UANL.

She chose the ICT career because he was recommended and did not really know what awaited him. Although the area that interested him was technical support. She believes that the university did not support him enough and that the teachers sometimes supported him to clarify her doubts. Suppose I don't finish because of the lack of support there was.

During the race I don't use the braille system, but I do use Jaws or NVDA screen readers.

In the matter that began to have problems was Programming Methodology, but the teacher did nothing and comments that she told him to do as she could.

She is currently studying Middle Technician in music at UANL
Next, we talk about the 2 cases that have concluded their studies.

The first subject of study is a woman, the cause of her blindness is microftalmia, which are small eyes. Between the ages of 5 and 6 , she learned the braille system and completed the entire primary school with this tool. Part of the high school continued using the braille machine and from the 2nd year on she began to use the computer and until today. Their family life is good, and their economic status is good. The high school was done at CECYTE (located at the UTSC facilities) considering the basis of its regular educational preparation.

Choose the ICT career because it is the one with the highest demand. During the race I do not use the braille system to take notes.

Considers that the support provided by the UTSC was sufficient and that the teachers did support it when in doubt.

The support tools she has used in her studies are screen readers such as JAWS or NVDA as well as other accessible programs to be able to program, since not all the programs that the teachers required to carry out the class were accessible with the readers of screen. The coexistence with her groupmates was good and she felt included.

In the areas that had problems it was in the programming in Java in which the Netbeans integrated development environment is used since this was not compatible with the screen reader. Then the teacher suggested another environment called Eclipse. This was a bit complicated since her classmates learned Java, with Netbeans, while she used Eclipse, so the instructions are different. Another problem was the programming in Android, since no other alternative was found to be able to be read by the screen reader software. Some obstacles that have been presented to him is that when she had to make a stay nobody wanted to hire her.

I only conclude the TSU in ICT because the schedule in which engineering is taught is in the evening and lives far away. On the other hand, she also wanted to continue her dream that is to study music. 
In the branch that feels more capable is in testing. In this case, because she likes to evaluate if the applications are accessible for people with visual disabilities or with any other type of disability.

Her expectations at the end of the race were to get a job of what she likes but this was not met.

Currently she works as a guide for the dialogue exhibition in the dark and is also studying at the music faculty.

The second case study of success is a man who is currently finishing Engineering in Information Technology and Communication in virtual mode, it should be noted that I also do the TSU in the same way.

The cause of his blindness is a tumor that developed at 5 years of age and ended up invading the optic nerves of both eyes.

His education was in public schools and he had to be the first and only student with visual impairment that was integrated.

His primary education was with an integrated support teacher to the school during the 6 years. His job was to provide assistance at all times, as well as teach him various support techniques that would serve him for later levels of education. These include the braille system and taking voice notes with a radio recorder.

In high school and high school, he was not assigned a support teacher. He always used himself, implementing the teaching strategies acquired in elementary school and receiving the support of each of the teachers who exchanged ideas with each other to help him. Among all, and with the support of his mother at home it was possible to conclude.

In high school 13 of the UANL, he completed his upper secondary education, this was the most difficult, although he managed to stand out before many classmates. Here he continues to use support tools such as taking voice notes in class, and at home he used a computer he was just learning to use for himself.

He has a very close family that supports him at all times and is aware of his concerns and desires to overcome. Its most difficult obstacle has been to overcome fear and seek ways to reintegrate into society and education.

ISSN 2524-2075

RINOE® All rights reserved
$\mathrm{He}$ considers that the bases of his previous preparation to the UTSC were good and he chooses the career of Information and Communication Technologies because he thinks it is the one with the highest demand.

Recognizes that the support provided by the UTSC is sufficient and that teachers have also supported it.

Some tools you have used are computers with internet access, Smartphone, Smartphone with voice recorder for class notes, etc. In this case you have not used braille to take notes, but you have used JAWS or NVDA.

In the areas that have had problems with the screen reader are networks, programming of desktop applications, web, and database.

The practices are when you have to make synoptic tables or concept maps, when you use Power point to make presentations, when you use the Packet tracer for network simulation, when you use the Net Beans IDE to program in Java, in the general design of the interfaces of desktop applications and web development, and in the design of database diagrams.

The teacher solved the situation, doing synthesis or summary instead of schemes, using Word instead of Power point, describing in some way the simulation of networks.

An attempt was made to use eclipse as a development environment instead of Netbeans. However, it was impossible for the teacher to support him in managing this environment; Finally, we chose to present as activity Java code and simulated structure in Word, evaluating the syntax and structures used.

For the development of applications, the interface design evaluation was omitted. Only the operation of the application or website was evaluated, as appropriate.

For the design of database schemas, we chose to use a description of the symbology to use a diagram, describing it as if it were really embodied.

Currently working for municipal government in the area of site, supporting the repair and maintenance of computers, as well as putting into practice the development of systems for the benefit of workers and citizens.

TOVAR-GONZÁLEZ, Claudia, GARCÍA-CEDILLO, David Rey and TIJERINA-MARTÍNEZ, Felipe. ITC, Is this a degree for blind people? Journal Health, Education and Welfare. 2019 
The coexistence with their group partners has always been good, receiving support from them and providing them, as far as possible.

In the ICT branch that feels more capable is the repair and maintenance of equipment. Although he is passionate about programming, database and computer networks, in which he recognizes that he needs to deepen.

His expectations at the end of the race are to be able to stand out in what he is passionate about and arrive one day to start his own business related to his profession.

Your current economic status is good because with your income you can afford some personal expenses, and even help your parents with household expenses.

\section{Conclusions}

In conclusion, it is determined that students with visual problems, whether they are visually impaired at 90 or up to $100 \%$, have problems in the Information and Communication Technologies career, because most applications are in visual format and not only at the process level. There are countries where the visually impaired are programming, but they are applying advanced technologies that not every institution has for the cost.

Some important points that are identified in the students interviewed are:

None of the respondents use the braille system to take notes.

The tools they use the most are JAWS and NVDA screen readers.

On the topic that everyone agrees is, that in the areas where they had the most difficulties are in the areas of visual programming, such as Web Development, Application Development II (Java), Application Development III (Android), where readers of screen does not work when designing screens. So students focus more on subjects where they can use touch, such is the case of the subject of Technical Support.

Another point is that when a student is blind from birth, it is very difficult for them to understand abstract terms of software development.
On the other hand, there are careers that are less visual and have more support at the audio level, something that does not happen with the ICT career since it is a $100 \%$ visual area.

You can teach programming concepts without visual environments, but it would not be of great help, because for companies, at the production level, programs with user-friendly help are sought and this is at the visual level.

\section{References}

Alberti, M., \& Romero, L. (2010). Alumnado con discapacidad visual. Barcelona: Editorial GRAÓ.

Alonso, C. (2008). Educar desde la discapacidad. España: Graó.

Ardanaz, L. (2004). La escuela inclusiva: practicas y reflexiones. España: Graó.

Batanero, J. M. (2015). Atención a la diversidad en el aula de Educación Infantil. Madrid: Ediciones Paraninfo S.A.

Escribano, A., \& Martinez, A. (2013). Inclusión educativa y profesorado inclusivo. Madrid: Narcea S.A. de Ediciones.

González, M. L., Sanchez Romero, C., \& González Lorenzo, J. M. (2016). Recursos tecnológicos en contextos educativos. Madrid: Universidad Nacional de educación a distancia.

Gutierrez, S. E., \& Serrano Marugan, I. (2010). Discapacidad sensorial: sordera, ceguera y sordoceguera. España: Editorial Sanz y Torres S.L.

Litovicius, P. (2011). E-learning para invidentes. España: EAE.

Morales, M. d. (2008). Modelos de funcionamiento en los centros de recursos educativos para personas con discapacidad visual en America Latina. España: Ministerio de Educación.

Palacios, S. G., Gallego Gil, D. J., \& Carretero Diaz, M. A. (2018). Materiales convencionales y tecnologicos para el tratamiento educativo de la diversidad. Madrid: Uned publicaciones.

TOVAR-GONZÁLEZ，Claudia，GARCÍA-CEDILLO, David Rey and TIJERINA-MARTÍNEZ, Felipe. ITC, Is this a degree for blind people? Journal Health, Education and Welfare. 2019 
Peña, R. M. (2011). Universidad 2020: Papel de las TIC en el nuevo entorno socioeconomico. Barcelona: Editorial Ariel S.A.

Rojas, D. G., Palomares Ruiz, A., \& (coords.). (2014). Una mirada a la realidad: propuestas innovadoras para favorecer la inclusión educativa. Toledo: Ediciones de la Universidad de Castilla-La Mancha.

Serna, M. C. (2011). Procesos educativos con TIC en la ciudad del conocimiento. Madrid: Piramide.

Zappalá, D., Köppel, A., \& Suchodolski, M. (2011). Inclusión de TIC en escuelas para alumnos con discapacidad visual. Buenos Aires: Ministerio de Educación de la Nación. 